\title{
An Experimental Study on a New Design of Double Slope Solar Still with External Flatted and Internal Parabolic Reflectors
}

\author{
M.S.El-Sebaey ${ }^{1}$, Sh. Shams El-Din ${ }^{2}$, M. Habib ${ }^{3}$ and A. El-Hanafy ${ }^{4}$ \\ ${ }^{1}$ (Mechanical Power Eng. Dept., Faculty of Engineering, Menoufia Uni., Egypt) \\ ${ }^{2}$ (Mechanical Power Eng. Dept., Faculty of Engineering, Menoufia Uni., Egypt) \\ ${ }^{3}$ (Mechanical Power Eng. Dept., Faculty of Engineering, Menoufia Uni., Egypt) \\ ${ }^{4}$ (Mechanical Power Eng. Dept., Faculty of Engineering, Menoufia Uni., Egypt)
}

\begin{abstract}
The world demand for potable water is increasing steadily with growing population. Desalination using solar energy is suitable for potable water production from brackish and seawater. In this paper, we presents design, fabrication and testing of double slope solar still with external flatted and internal parabolic reflectors and also optimization of external flat reflector tilt angle for Egyptian climatic conditions. The external flat reflector tilted at $\left(30^{\circ}, 45^{\circ}, 60^{\circ}\right.$ and $\left.75^{\circ}\right)$ on the horizontal plane. The depth of water inside basin still is $1 \mathrm{~cm}$. Experimental results were compared with conventional double slope solar still. Optimum tilt angle is found to be $60^{\circ}$ with a maximum daily productivity of $9.89 \mathrm{lit} / \mathrm{m}^{2}$.
\end{abstract}

Keywords : Solar desalination, Still Productivity, Performance, Heat and Mass transfer.

\section{INTRODUCTION}

Clean water is essential for good health which influences the social and economic development of any nation. People who use contaminated water are prone to waterborne diseases and they cannot effectively engage themselves in economic activities. Moreover, financial resources that could have been allocated to developmental projects are channelled to disease-curing efforts. Consequently, ill health contributes to the retardation of economic growth.

The shortage of drinking water is expected to be the biggest problem of the world in this century due to unsustainable consumption rates and population growth. Pollution of fresh water resources (rivers, lakes and underground water) by industrial wastes has heightened the problem.

Water is one of the most abundant resources on earth, covering three fourths of the planet's surface. About $97 \%$ of the earth's water is salt water in the oceans covering three fourths of the planet's surface covering three fourths of the planet's surface. About $97 \%$ of the earth's water is salt water in the oceans and $3 \%$ (about 36 million $\mathrm{km}^{3}$ ) is fresh water contained in the poles (in the form of ice), ground water, lakes and rivers, which supply most of human and animal needs. Nearly, $70 \%$ from this tiny $3 \%$ of the world's fresh water is frozen in glaciers, permanent snow cover, ice and permafrost. Thirty percent of all fresh water is underground, most of it in deep, hard-to-reach aquifers. Lakes and rivers together contain just a little more than $0.25 \%$ of all fresh water; lakes contain most of it [1].

Water is a basic necessity for sustaining life on the earth. With the passage of time due to technological usage and their waste disposal along with ignorance of human being caused water pollution which led the world to water scarcity. Due to water pollution the surface and under ground water reservoirs are now highly contaminated. The demand of fresh water is increasing with growth in human population. To meet the demand of potable water, scientists have developed various technologies such as reverse osmosis (RO), vapour compression (VC) and electro dialysis (ED) [2]. These water purification methods are highly energy and cost intensive. It is well known that desalination plants use electrical energy which have both economical and environmental drawbacks and rely on conventional fuels [3]. Therefore a method is required to use renewable energy, low input cost and less effort for the production of potable water.

Solar distillation is a thermal desalination method where solar energy is used to distill fresh water from saline and brackish water. A distillation is one of many processes available for water purification, and sunlight is one of several forms of heat energy that can be used to power that process. Sunlight has the advantage of zero fuel cost but it requires more space for its collection. It is a great practical alternative, which offers life to those regions where the lack of fresh water hinders development [4]. Solar water distillation is a solar technology with a very long history, and installations were found to be built over 2000 years ago, to produce salt rather than drinking water. An early large-scale solar still was built in 1874 to supply drinking water to mining community in Chile. Mass production occurred for the first time during the Second World War [5]. 
Solar distillation systems can be small or large. They are designed either to serve the needs of single family, producing from 1 to 4 lit of drinking water a day on the average, or to produce much greater amounts for an entire neighborhood or village. In some parts of the world the scarcity of fresh water is partially overcome by covering shallow salt-water basins with glass in green house- like structures. These solar energy distilling plants are relatively inexpensive, low technology systems, especially useful where the need for small plants exists [6].

Different designs of solar still have emerged. Double slop solar still is a relatively simple device to construct and operate. However, the low productivity of the solar still triggered the initiatives to look for ways to improve its productivity and performance. These may be classified into passive and active methods.

In this work; theoretical and experimental investigation on a new passive solar distillation system (double slope solar with external flatted and internal parabolic reflectors) are carried out. This study optimizes the external reflector tilt angle to found the maximum output in Egyptian climatic conditions.

\subsection{Experimental Set-up}

\section{MATERIALS AND MethodS}

\subsubsection{Double Slope Solar Still}

The solar still is consists mainly of a rectangular shaped with black painted basin surfaces. The still basin is used to magnify the amount of solar energy absorbed to increase the quantity of distilled water produced. The single basin double slope solar still has been fabricated with galvanized iron plate. The overall size of the inner basin is $1000 \mathrm{~mm} \times 500 \mathrm{~mm} \times 120 \mathrm{~mm}$ and that of the outer basin is $1100 \mathrm{~mm} \times 600 \mathrm{~mm} \times 170$ $\mathrm{mm}$. The gap between the inner and outer basin is packed with wood chips as insulation material to reduce the heat loss from the inner basin to the outlet. The frame of the outer basin is made of wood sheets. The top condensing cover is consists of glasses sheets of thickness $4 \mathrm{~mm}$ inclined at $21^{\circ}$ on both sides.

The schematic diagram and photograph of the double slope solar still are shown in Figures. 1a and 1b, respectively. The condensate water is collected in the - V - and inverted - V - shaped drainage supported below the glass lower edge on both sides. The condensate collected from both sides of the still is continuously drained through flexible hose and stored into an external measuring jar. To keep a constant height of the water in the basin, a small hole of $5 \mathrm{~mm}$ in the glass cover is provided for water inlet. Another small hole in the glass cover is used to insert the thermocouples for measuring the seawater, base of basin; air water vapour and inner glass cover temperatures. The holes are closed with the insulating material to avoid the heat and vapour loss.

\subsubsection{Double Slope Solar Still with External Flatted and Internal Parabolic Reflectors}

The double slope solar still with external flatted and internal parabolic reflectors is a concentrating type of passive solar distillation system. The still consists of a number of mirrors to produce parabolic reflector $1200 \mathrm{~mm}$ long x $1500 \mathrm{~mm}$ wide with a focal length of $375 \mathrm{~mm}$. The still condensing cover is made of $4 \mathrm{~mm}$ thick simple window glass inclined at $21^{\circ}$ with horizontal. The frame of the outer still is made of wood sheets. The reflector was designed to concentrate the incident solar radiation on the black outside surface of the basin .The basin area of $1000 \mathrm{~mm} \times 500 \mathrm{~mm}$ is fabricated by using a galvanized iron sheet of $0.8 \mathrm{~mm}$ thickness located on the focal line of the reflector. An external flat reflector of $1200 \mathrm{~mm}$ x $1500 \mathrm{~mm}$ was used.

The schematic diagram and photograph of modified double slope solar are shown in Figures. 2a and $2 \mathrm{~b}$, respectively. The glass cover allows solar radiation to pass into the still. Here, the upper blackened of the basin absorbed part of solar radiation. The remaining amount falling on the glass cover fall on the concave mirrors and then reflected on the bottom blackened base down.

The devices inclination angle to the horizontal plane are fixed at $30.33^{\circ} \mathrm{N}$ (latitude of Shebin ElKom) to receive the maximum solar radiation during test period.

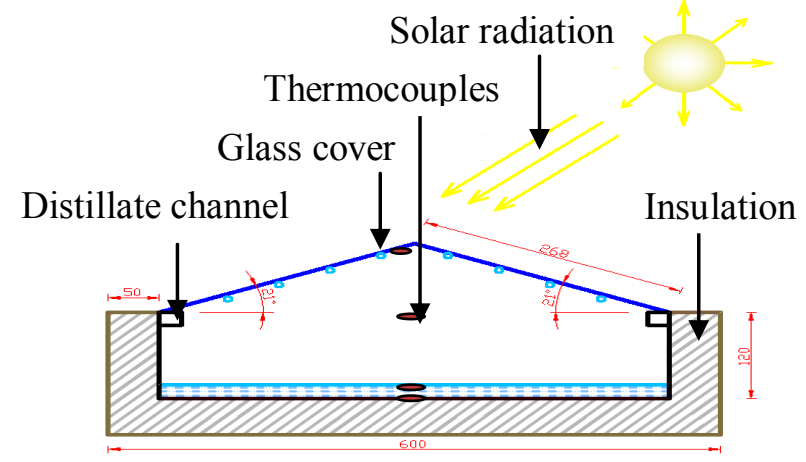

Fig .1a Schematic diagram of the double slope solar still

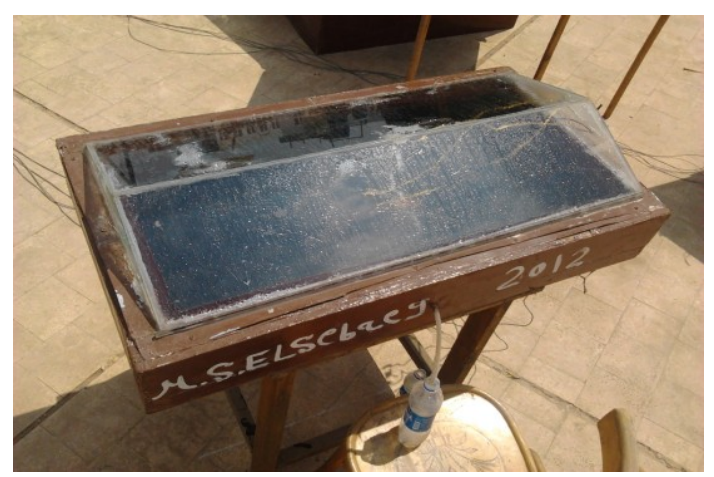

Fig .1b Photograph of the double slope solar still 


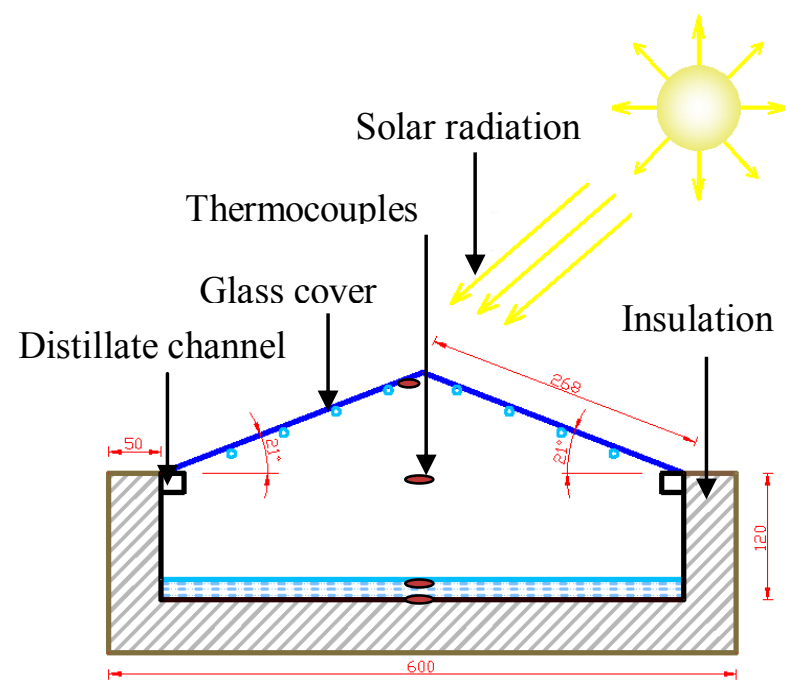

Fig .2a Schematic diagram of double slope solar still with external flatted and internal parabolic reflectors reflectors

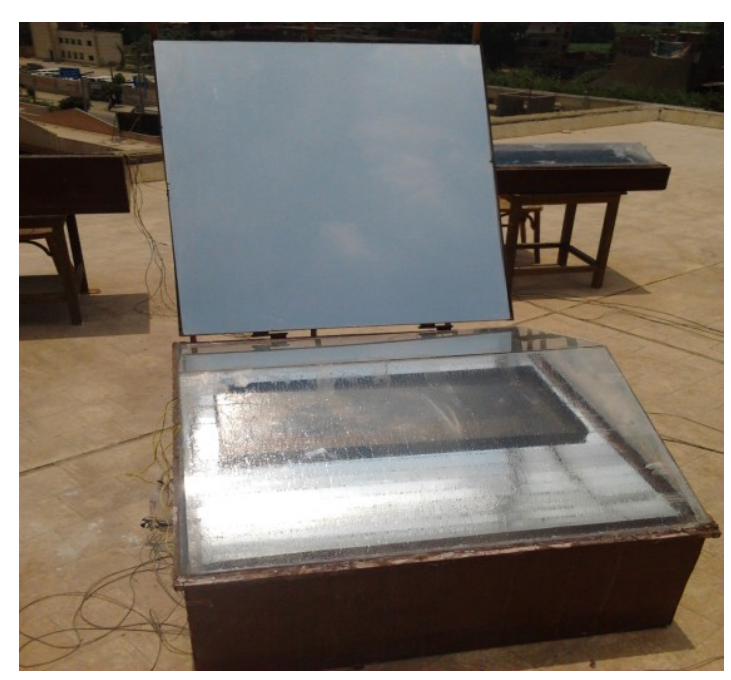

Fig .2b Photograph of double slope solar still with external flatted and internal parabolic reflectors

\subsection{Measurements and Instrumentation}

The measuring instruments used in this work include the measured weather conditions; global incident solar radiation on a horizontal surface and ambient air temperature $\mathrm{T}_{\mathrm{a}}$, still productivity, inner glass cover temperature $T_{g}$, water-vapour temperature inside each still $T_{v}$, water temperature $T_{w}$ and basin temperature.

Eppley Pyranometer was used to measure the global solar radiation.

During each test, fresh water productivity is measured periodically every 60 minute using graduated cylinder with an uncertainty of $\pm 1 \mathrm{ml}$.

Eight Calibrated Chromel-Alumel thermocouples (Type-K) were used to measure the temperatures inside solar stills. The thermocouples were fixed inside each still at four different positions to measure the inner basin temperature, basin water temperature, water-vapour temperature and inner glass cover temperature. The thermocouples readings are taken using calibrated digital temperature reader (Temperature Controller Device) with an uncertainty of $\pm 0.05{ }^{\circ} \mathrm{C}$. The ambient air temperature was measured by mercury thermometer with an accuracy of $\pm 0.5^{\circ} \mathrm{C}$.

\subsection{External heat transfer}

\section{THERMAL MODELING}

The external heat transfer is mainly governed by conduction, convection and radiation processes which are independent of each other.

These processes cover the heat transfer between the solar still and the surroundings; the heat transfer from the glass to the ambient and the heat transfer from the bottom and sides. The following heat transfer coefficients are considered:

\subsubsection{Top loss coefficient}

Due to the small thickness of the glass cover $(4 \mathrm{~mm})$, the temperature of the glass may be assumed to be uniform. The external convection and radiation losses from the glass cover to outside atmosphere can be expressed as:

Where

$$
\dot{\mathrm{q}}_{\mathrm{g}}=\dot{\mathrm{q}}_{\mathrm{cg}}+\dot{\mathrm{q}}_{\mathrm{rg}}
$$

$$
\begin{aligned}
& \dot{\mathrm{q}}_{\mathrm{cg}}=\mathrm{h}_{\mathrm{cg}}\left(\mathrm{T}_{\mathrm{g}}-\mathrm{T}_{\mathrm{a}}\right) \\
& \dot{\mathrm{q}}_{\mathrm{rg}}=\mathrm{h}_{\mathrm{rg}}\left(\mathrm{T}_{\mathrm{g}}-\mathrm{T}_{\mathrm{a}}\right)
\end{aligned}
$$

The glass cover convective heat transfer coefficient $\left(\mathrm{h}_{\mathrm{cg}}\right)$ is a function of the wind velocity $(\mathrm{v})$. The value of $\left(\mathrm{h}_{\mathrm{cg}}\right)$ is given by the following empirical relation [7]: 


$$
\mathrm{h}_{\mathrm{cg}}=\left(\begin{array}{cc}
{[5.7+3.8 \times \mathrm{v}] ;} & \mathrm{v} \leq 5 \mathrm{~m} / \mathrm{s} \\
{\left[6.15 \times \mathrm{v}^{0.8}\right] ;} & \mathrm{v}>5 \mathrm{~m} / \mathrm{s}
\end{array}\right)
$$

[7]:

The glass cover radiative heat transfer coefficient $\left(\mathrm{h}_{\mathrm{rg}}\right)$ can be evaluated from the following equation

$$
\begin{gathered}
\mathrm{h}_{\mathrm{rg}}=\frac{\varepsilon_{\mathrm{g}} \times \sigma \times\left(\mathrm{T}_{\mathrm{g}}^{4}-\mathrm{T}_{\text {sky }}^{4}\right)}{\left(\mathrm{T}_{\mathrm{g}}-\mathrm{T}_{\mathrm{a}}\right)} \\
\mathrm{T}_{\text {sky }}=\mathrm{T}_{\mathrm{a}}-6
\end{gathered}
$$

By substituting $\left(\dot{\mathrm{q}}_{\mathrm{cg}}\right)$ and $\left(\dot{\mathrm{q}}_{\mathrm{rg}}\right)$ into Eq. 1, Eq. 7 can be formulated:

$$
\dot{\mathrm{q}}_{\mathrm{g}}=\mathrm{h}_{\mathrm{tg}} \times\left(\mathrm{T}_{\mathrm{g}}-\mathrm{T}_{\mathrm{a}}\right)
$$

Where $\left(h_{\mathrm{tg}}\right)$ is the total glass heat transfer loss coefficient by convection and radiation from glass to the ambient:

$$
\mathrm{h}_{\mathrm{tg}}=\mathrm{h}_{\mathrm{cg}}+\mathrm{h}_{\mathrm{rg}}
$$

\subsubsection{Bottom and sides loss coefficient}

Heat is also lost from the water in the basin to the ambient through bottom and side surfaces by convection, radiation and conduction. The overall bottom loss coefficient $\left(\mathrm{U}_{\mathrm{b}}\right)$ can be written as:

$$
\mathrm{U}_{\mathrm{b}}=\frac{1}{\frac{1}{\mathrm{~h}_{\mathrm{w}}}+\frac{\mathrm{L}_{\text {ins }}}{\mathrm{K}_{\text {ins }}}+\left(\frac{\mathrm{h}_{\mathrm{cb}}+\mathrm{h}_{\mathrm{rb}}}{\mathrm{h}_{\mathrm{cb}} \times \mathrm{h}_{\mathrm{rb}}}\right)}
$$

Where

$$
\mathrm{h}_{\mathrm{b}}=\frac{1}{\frac{\mathrm{L}_{\text {ins }}}{\mathrm{K}_{\text {ins }}}+\left(\frac{\mathrm{h}_{\mathrm{cb}}+\mathrm{h}_{\mathrm{rb}}}{\mathrm{h}_{\mathrm{cb}} \times \mathrm{h}_{\mathrm{rb}}}\right)}
$$

The values of $\left(h_{c b}+h_{r b}\right)$ can be obtained from Eq. 1 by substituting $(v=0)$ because there is no wind velocity at the bottom of the insulation.

Similarly, the side heat loss coefficient $\left(\mathrm{U}_{\mathrm{e}}\right)$ can be approximated as:

$$
\mathrm{U}_{\mathrm{e}}=\mathrm{U}_{\mathrm{b}} \times\left(\frac{\mathrm{A}_{\mathrm{ss}}}{\mathrm{A}_{\mathrm{s}}}\right)
$$

If the side still area $\left(A_{s s}\right)$ is very small compared with $\left(A_{s}\right)$, then $\left(U_{e}\right)$ can be neglected [8].

\subsection{Internal heat transfer}

Heat transfer within the solar still is referred to be as the internal heat transfer; which mainly consists of radiation, convection and evaporation that occurs between the water surface and glass cover. These three modes of internal heat transfer are discussed as follows [9]:

\subsubsection{Radiation loss coefficient}

It is known that radiation heat transfer occurs between any two bodies when there is a temperature difference between them. Considering the water surface and glass cover, the radiation between the water and the glass can be given by:

$$
\dot{\mathrm{q}}_{\mathrm{rw}}=\mathrm{h}_{\mathrm{rw}} \times\left(\mathrm{T}_{\mathrm{w}}-\mathrm{T}_{\mathrm{g}}\right)
$$

The radiative heat transfer is given by Stefan Boltz man's equation as below [5]:

$$
\dot{\mathrm{q}}_{\mathrm{rw}}=\varepsilon_{\mathrm{eff}} \times \sigma \times\left[\left(\mathrm{T}_{\mathrm{w}}+273\right)^{4}-\left(\mathrm{T}_{\mathrm{g}}+273\right)^{4}\right]
$$

Eliminating $\left(\mathrm{h}_{\mathrm{rw}}\right)$ from both the equations we get:

Also,

$$
\begin{gathered}
\mathrm{h}_{\mathrm{rw}}=\frac{\varepsilon_{\text {eff }} \times \sigma \times\left[\left(\mathrm{T}_{\mathrm{w}}+273\right)^{4}-\left(\mathrm{T}_{\mathrm{g}}+273\right)^{4}\right]}{\left(\mathrm{T}_{\mathrm{w}}-\mathrm{T}_{\mathrm{g}}\right)} \\
\mathrm{h}_{\mathrm{rw}}=\varepsilon_{\mathrm{eff}} \times \sigma \times\left[\left(\mathrm{T}_{\mathrm{w}}+273\right)^{2}+\left(\mathrm{T}_{\mathrm{g}}+273\right)^{2}\right] \times\left(\mathrm{T}_{\mathrm{w}}+\mathrm{T}_{\mathrm{g}}+546\right)
\end{gathered}
$$


The effective emittance between the water surface and the glass cover can be presented by:

$$
\varepsilon_{\text {eff }}=\left[\frac{1}{\varepsilon_{\mathrm{w}}}+\frac{1}{\varepsilon_{\mathrm{g}}}-1\right]^{-1}
$$

The values of the constants will be $\left(\varepsilon_{\mathrm{w}}=0.96\right),\left(\varepsilon_{\mathrm{g}}=0.88\right)$.

\subsubsection{Convective loss coefficient}

Free convection occurs across the humid air in the enclosure, due to the temperature difference between the water surface and the glass cover. The convective heat transfer rate can be obtained from the following equation:

$$
\dot{\mathrm{q}}_{\mathrm{cw}}=\mathrm{h}_{\mathrm{cw}} \times\left(\mathrm{T}_{\mathrm{w}}-\mathrm{T}_{\mathrm{g}}\right)
$$

The convective heat loss coefficient $\left(h_{c w}\right)$ is obtained from the following expression:

$$
\begin{gathered}
\mathrm{Nu}=\frac{\mathrm{h}_{\mathrm{cw}} \times \mathrm{x}}{\mathrm{k}}=\mathrm{C}[\mathrm{Gr} \times \operatorname{Pr}]^{\mathrm{n}} \\
\operatorname{Pr}=\frac{\mu \times \mathrm{C}_{\mathrm{p}}}{\mathrm{k}} \\
\mathrm{Gr}=\frac{\mathrm{g} \beta \rho^{2}(\mathrm{x})^{3}\left(\Delta \mathrm{T}^{\prime}\right)}{\mu^{2}}
\end{gathered}
$$

To calculate the physical properties of humid air, the standard equations are used [10]. These properties are given in Table 1.

The effective temperature difference $\Delta \mathrm{T}^{\prime}$ is given by:

$$
\Delta \mathrm{T}^{\prime}=\mathrm{T}_{\mathrm{W}}-\mathrm{T}_{\mathrm{g}}+\frac{\left(\mathrm{P}_{\mathrm{w}}-\mathrm{P}_{\mathrm{g}}\right) \times\left(\mathrm{T}_{\mathrm{w}}+273\right)}{268.9 \times 10^{3}-\mathrm{P}_{\mathrm{w}}}
$$

From Eq. 17; it is seen that $\left(\mathrm{h}_{\mathrm{cw}}\right)$ depends upon two constants values $(\mathrm{C})$ and $(\mathrm{n})$. Various researchers have given different values of $(\mathrm{C})$ and $(\mathrm{n})$ for different Grashoff number ranges.

For average spacing $\mathrm{x} \geq 0.25 \mathrm{~m}$; Dunkle [11] has taken the value of $\mathrm{C}=0.075$ and $\mathrm{n}=1 / 3$ for $\mathrm{Gr} \geq$ $4.39 \times 10^{5}$. The expression for $\left(\mathrm{h}_{\mathrm{cw}}\right)$ is given as:

$$
\mathrm{h}_{\mathrm{cw}}=0.884\left[\left(\mathrm{~T}_{\mathrm{w}}-\mathrm{T}_{\mathrm{g}}\right)+\frac{\left(\mathrm{P}_{\mathrm{w}}-\mathrm{P}_{\mathrm{g}}\right) \times\left(\mathrm{T}_{\mathrm{w}}+273\right)}{268.9 \times 10^{3}-\mathrm{P}_{\mathrm{w}}}\right]^{1 / 3}
$$

Where $\left(\mathrm{P}_{\mathrm{w}}\right)$ and $\left(\mathrm{P}_{\mathrm{g}}\right)$ are the vapour pressures at water and glass temperatures and can be expressed by the following equations respectively:

$$
\begin{aligned}
& P_{w}=\exp \left[25.317-\left(\frac{5144}{273+T_{w}}\right)\right] \\
& P_{g}=\exp \left[25.317-\left(\frac{5144}{273+T_{g}}\right)\right]
\end{aligned}
$$

Table 1, Physical properties of humid air as function of vapour temperature [10]

\begin{tabular}{|c|c|c|c|}
\hline Physical constants & Symbol & Units & Expressions \\
\hline Specific heat capacity & $\mathrm{C}_{\mathrm{P}}$ & $\mathrm{J} / \mathrm{kg} / \mathrm{K}$ & $\mathrm{C}_{\mathrm{P}}=999.2+0.1434 \mathrm{~T}_{\mathrm{v}}+1.101 \times 10^{-4} \mathrm{~T}_{\mathrm{v}}^{2}-6.758 \times 10^{-8} \mathrm{~T}_{\mathrm{v}}^{3}$ \\
\hline Thermal conductivity & $\mathrm{k}$ & $\mathrm{W} / \mathrm{m}^{\circ} \mathrm{C}$ & $\mathrm{k}=0.0244+0.7673 \times 10^{-4} \mathrm{~T}_{\mathrm{v}}$ \\
\hline Viscosity & $\mu$ & $\mathrm{N} . \mathrm{S} / \mathrm{m}^{2}$ & $\mu=1.718 \times 10^{-5}+4.62 \times 10^{-8} \mathrm{~T}_{\mathrm{v}}$ \\
\hline Density & $\rho$ & $\mathrm{Kg} / \mathrm{m}^{3}$ & $\rho=353.44 /\left(\mathrm{T}_{\mathrm{v}}+273.15\right)$ \\
\hline Expansion factor & $\beta$ & $\mathrm{K}-1$ & $\beta=1 /\left(\mathrm{T}_{\mathrm{v}}+273.15\right)$ \\
\hline
\end{tabular}

\subsubsection{Evaporation loss coefficient}

It is necessary for the evaporation loss coefficient to find out the evaporation pressure occurring inside the still and acting on the glass and the water surfaces. Due to condensation of the rising vapour on the glass cover, 
there is heat loss by evaporation between the water surface and the glass cover. This can be expressed by the following empirical equation [12]:

Also,

$$
\begin{gathered}
\dot{\mathrm{q}}_{\mathrm{ew}}=\mathrm{h}_{\mathrm{ew}} \times\left(\mathrm{T}_{\mathrm{w}}-\mathrm{T}_{\mathrm{g}}\right) \\
\dot{\mathrm{q}}_{\mathrm{ew}}=16.273 \times 10^{-3} \times \mathrm{h}_{\mathrm{cw}} \times\left(\mathrm{P}_{\mathrm{w}}-\mathrm{P}_{\mathrm{g}}\right)
\end{gathered}
$$

Here, $\left(h_{e w}\right)$ is the evaporative heat transfer coefficient and is given by:

$$
h_{e w}=16.273 \times 10^{-3} \times h_{c w} \times\left(\frac{P_{w}-P_{g}}{T_{w}-T_{g}}\right)
$$

The total heat transfer coefficient from water to glass can be obtained by the summation of all these three heat transfer coefficients. Thus,

And

$$
\begin{aligned}
& \mathrm{h}_{\mathrm{tw}}=\mathrm{h}_{\mathrm{cw}}+\mathrm{h}_{\mathrm{ew}}+\mathrm{h}_{\mathrm{rw}} \\
& \dot{\mathrm{q}}_{\mathrm{tw}}=\dot{\mathrm{q}}_{\mathrm{cw}}+\dot{\mathrm{q}}_{\mathrm{ew}}+\dot{\mathrm{q}}_{\mathrm{rw}}
\end{aligned}
$$

\subsection{Evaluation of distillate output}

The hourly distillate output per $\mathrm{m}^{2}$ from the solar distillation unit can be obtained as:

$$
\begin{gathered}
\dot{\mathrm{M}}_{\mathrm{w}}=\frac{\dot{\mathrm{q}}_{\mathrm{ew}} \times 3600}{\mathrm{~L}} \\
\dot{\mathrm{M}}_{\mathrm{w}}=\frac{\mathrm{h}_{\mathrm{ew}} \times\left(\mathrm{T}_{\mathrm{w}}-\mathrm{T}_{\mathrm{g}}\right) \times 3600}{\mathrm{~L}}
\end{gathered}
$$

Where (L) is the latent heat of humid air in $\mathrm{J} / \mathrm{kg}$ and is given by the expression [10]:

$$
\mathrm{L}=3.1615 \times 10^{6} \times\left[1-\left(7.6166 \times 10^{-4} \times \mathrm{T}_{\mathrm{w}}\right)\right]
$$

Where $\left(T_{w}\right)$ is in $K$, and $(L)$ is obtained also from the steam tables.

There are percentage deviations between the theoretical and experimental distillate outputs, and hence, there is a need to modify the value of constants $(C)$ and $(n)$ in the expression $\left(\mathrm{Nu}=\mathrm{C}[\mathrm{Ra}]^{\mathrm{n}}\right)$ from which $\left(\mathrm{h}_{\mathrm{cw}}\right)$ is obtained. This modification, using the experimental distillate output $\left(\dot{M}_{w}\right)$ is obtained as follows:

$$
\begin{gathered}
\mathrm{Nu}=\mathrm{C}[\mathrm{Ra}]^{\mathrm{n}} \\
\mathrm{Nu}=\frac{\mathrm{h}_{\mathrm{cw}} \times \mathrm{x}}{\mathrm{k}}=\mathrm{C}[\mathrm{Ra}]^{\mathrm{n}}=\mathrm{C}[\mathrm{Gr} \times \operatorname{Pr}]^{\mathrm{n}} \\
\mathrm{h}_{\mathrm{cw}}=\frac{\mathrm{k}}{\mathrm{x}} \times \mathrm{C}[\mathrm{Ra}]^{\mathrm{n}}
\end{gathered}
$$

$$
\dot{\mathrm{M}}_{\mathrm{w}}=\frac{\dot{\mathrm{q}}_{\mathrm{ew}} \times 3600}{\mathrm{~L}}
$$

Now,

$$
\begin{gathered}
\dot{\mathrm{M}}_{\mathrm{w}}=16.273 \times 10^{-3} \times \frac{\mathrm{k}}{\mathrm{x}} \times \mathrm{C}[\mathrm{Ra}]^{\mathrm{n}} \times\left(\mathrm{P}_{\mathrm{w}}-\mathrm{P}_{\mathrm{g}}\right) \times \frac{3600}{\mathrm{~L}} \\
\mathrm{R}=16.273 \times 10^{-3} \times \frac{\mathrm{k}}{\mathrm{x}} \times\left(\mathrm{P}_{\mathrm{w}}-\mathrm{P}_{\mathrm{g}}\right) \times \frac{3600}{\mathrm{~L}}
\end{gathered}
$$

For a given steady state conditions, the value of $\mathrm{R}$ is constant so,

$$
\begin{aligned}
& \dot{\mathrm{M}}_{\mathrm{w}}=\mathrm{R} \times \mathrm{C}[\mathrm{Ra}]^{\mathrm{n}} \\
& \frac{\dot{\mathrm{M}}_{\mathrm{w}}}{\mathrm{R}}=\mathrm{C}[\mathrm{Ra}]^{\mathrm{n}}
\end{aligned}
$$

Taking the logarithm to both sides of Eq. (40) and comparing it with the straight line equation,

$$
\mathrm{y}=\mathrm{mx}+\mathrm{C}_{\mathrm{o}}
$$


We get

$$
\mathrm{y}=\ln \left(\frac{\dot{\mathrm{M}}_{\mathrm{w}}}{\mathrm{R}}\right), \mathrm{C}_{\mathrm{O}}=\ln \mathrm{C}, \mathrm{x}=\ln (\mathrm{Ra})
$$

and

$\mathrm{m}=\mathrm{n}$

Using a linear regression analysis, the coefficients in Eq. (41) $\mathrm{m}$ and $\mathrm{C}_{\mathrm{O}}$ can be obtained by the following expressions:

$$
\begin{gathered}
\mathrm{m}=\frac{\mathrm{N}\left(\sum \mathrm{xy}\right)-\left(\sum \mathrm{x}\right)\left(\sum \mathrm{y}\right)}{\mathrm{N}\left(\sum \mathrm{x}^{2}\right)-\left(\sum \mathrm{x}\right)^{2}} \\
\mathrm{C}_{\mathrm{O}}=\frac{\left(\sum \mathrm{y}\right)\left(\sum \mathrm{x}^{2}\right)-\left(\sum \mathrm{x}\right)\left(\sum \mathrm{xy}\right)}{\mathrm{N}\left(\sum \mathrm{x}^{2}\right)-\left(\sum \mathrm{x}\right)^{2}}
\end{gathered}
$$

Where $\mathrm{N}$ is number of experimental observations for steady state condition and becomes $\mathrm{N}+1$ in quasi steady state condition as in the case of this experiment.

\section{RESUlTS AND DISCUSSION}

Experimental tests were carried out in four successive days during $26^{\text {th }}$ till $30^{\text {th }}$ of June, 2013 to ensure the same climatic conditions. Figure .3 shows the variation of solar radiation and ambient temperature with the local time. During the day from sunrise to sunset, the solar radiation and ambient temperature increases gradually and reaches a maximum value at around noon period and then it decreases. The glass covers allows the solar radiation to pass through them and traps the solar energy inside the still. Due to this process of evaporation, the salts and other bacteria are left behind in the basin while the water evaporates. When the condensate drops reaches its threshold size, they start flowing downward under the influence of gravity and the obtained distilled water is collected.

Figure. 4 shows the daily productivity of solar still with $1 \mathrm{~cm}$ water depth at different tilt angles of external flat reflector. It is seen that the productivity changes from $30^{\circ}$ up to $75^{\circ}$. The productivity increases from the external reflector angle of $30^{\circ}$ up to $60^{\circ}$ and then decreases. The best tilt angle of the external reflector is found to be $60^{\circ}$ with a maximum daily productivity of $9.89 \mathrm{lit} / \mathrm{m}^{2}$. The percentage increase in the productivity of $4.48 \%$ was observed when the angle was changed between $30^{\circ}$ and $45^{\circ}$ and an increase of $13.5 \%$ from $45^{\circ}$ to $60^{\circ}$ was also recorded. However, a decrease of $12.94 \%$ was observed when the angle was changed from $60^{\circ}$ to $75^{\circ}$.

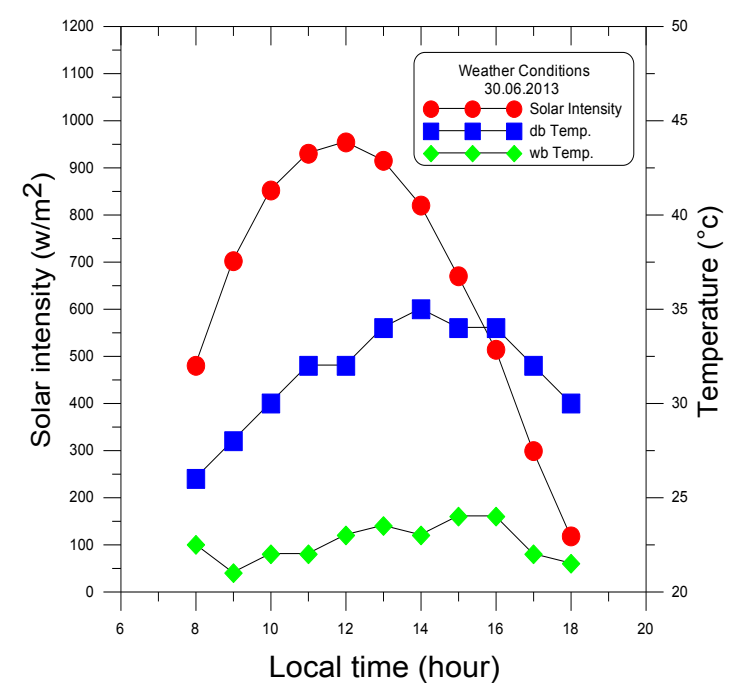

Fig .3 Hourly variation of solar radiation and ambient temperature (30.06.2013)

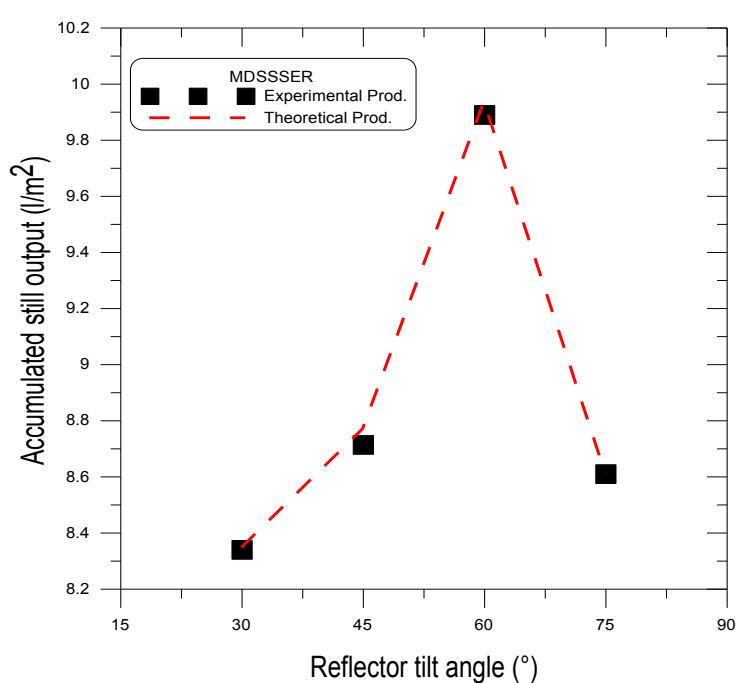

Fig .4 Accumulated productivity for modified double slope solar still for different external reflector tilt angles

The temperature profiles for the basin, water, vapour and the glass cover for both conventional and modified double slope solar stills are shown in the Figure. 5 and Figures. 6a, 6b, 6c and $6 \mathrm{~d}$ respectively. It can be seen that a gradually increase in the water temperature occurs and reaches the maximum value in the afternoon period. This is due to the increase in the absorbed solar radiation that exceeds the losses to the atmosphere. After the period of $2 \mathrm{PM}$, the water temperature decreases due to the losses from the solar still which becomes larger than the absorbed solar radiation. When the glass temperature is smaller than the water temperature, it causes condensation of water vapor on the glass. In the early hours of the morning the difference 
in glass temperature and the water temperature is smaller which causes smaller productivity. This is because the small energy absorbed by the water at these periods.

Figures. $7 \mathrm{a}$ and $7 \mathrm{~b}$ shows the variation of the water and inner glass surface temperatures for modified solar still with external reflector angles of $30^{\circ}, 45^{\circ}, 60^{\circ}$ and $75^{\circ}$ at water depth of $1 \mathrm{~cm}$ respectively. it is seen that the water and inner glass surface temperatures in the morning period are maximum with external reflector angle of $75^{\circ}$, showing maximum received energy and hence the maximum productivity. However, at later periods of the day these temperatures are the maximum with external reflector angle of $60^{\circ}$ indicating the increase in productivity of the still compared to other external reflector angles.

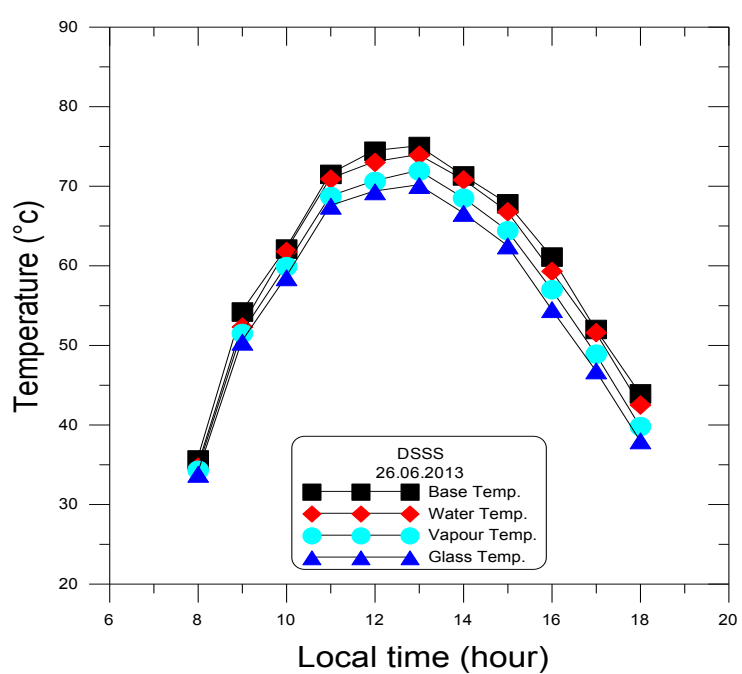

Fig .5 Hourly variation of various temperatures of conventional double slope solar still with local time (29.06.2013)

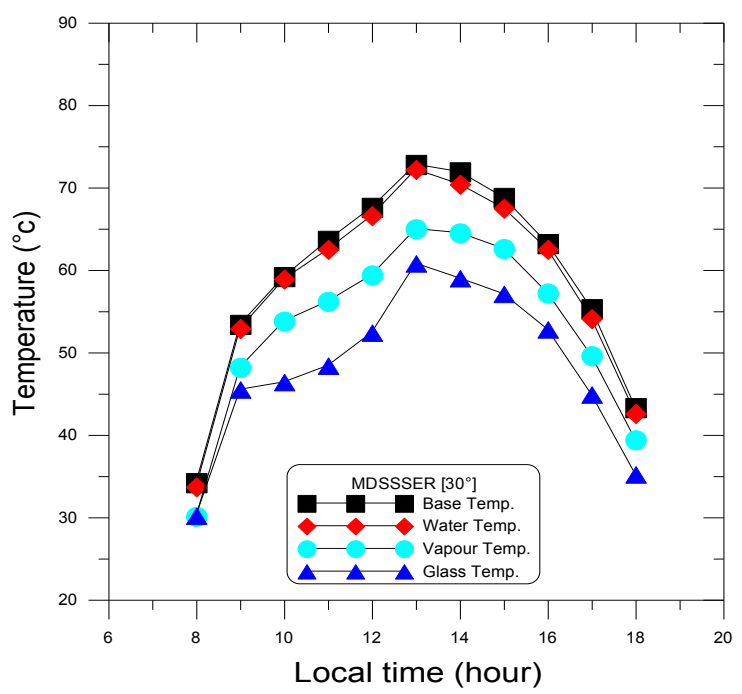

Fig .6a Hourly variation of various temperatures of modified still with external reflector angle of $30^{\circ}$ with local time (26.06.2013)

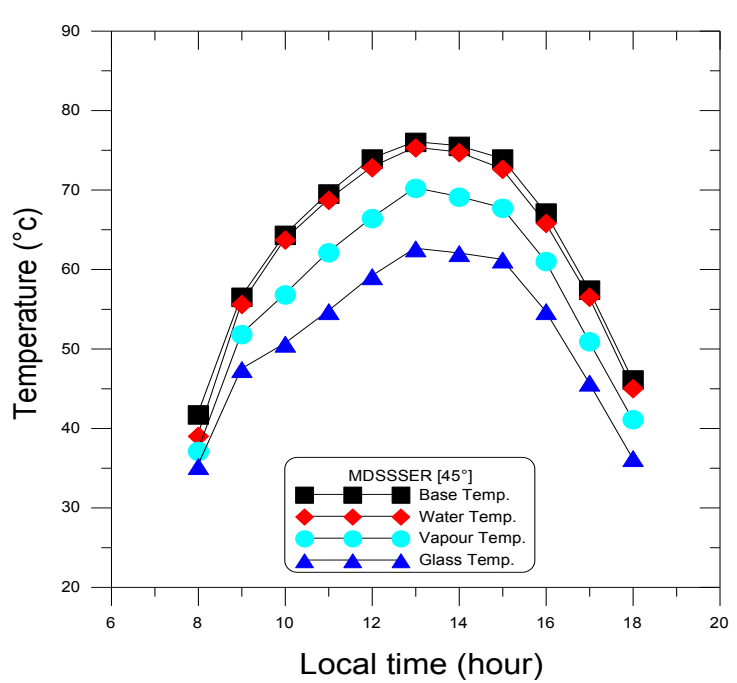

Fig .6b Hourly variation of various temperatures of modified still with external reflector angle of $45^{\circ}$ with local time (27.06.2013)

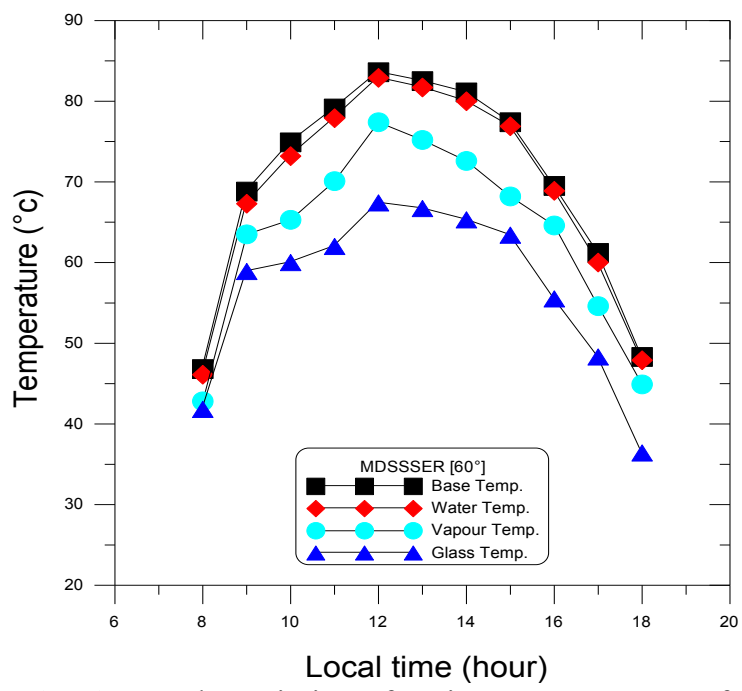

Fig .6c Hourly variation of various temperatures of modified still with external reflector angle of $60^{\circ}$ with local time (29.06.2013) 


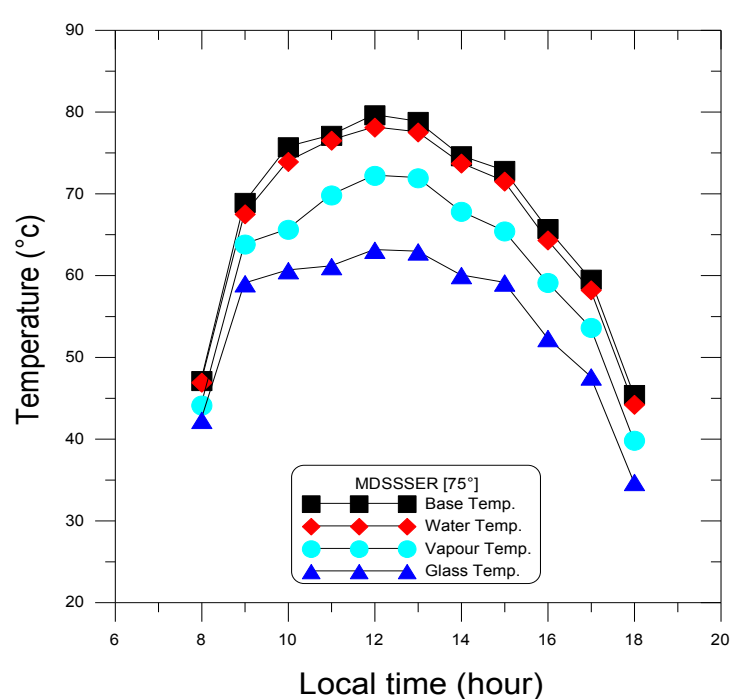

Fig .6d Hourly variation of various temperatures of modified still with external reflector angle of $75^{\circ}$ with local time $(30.06 .2013)$

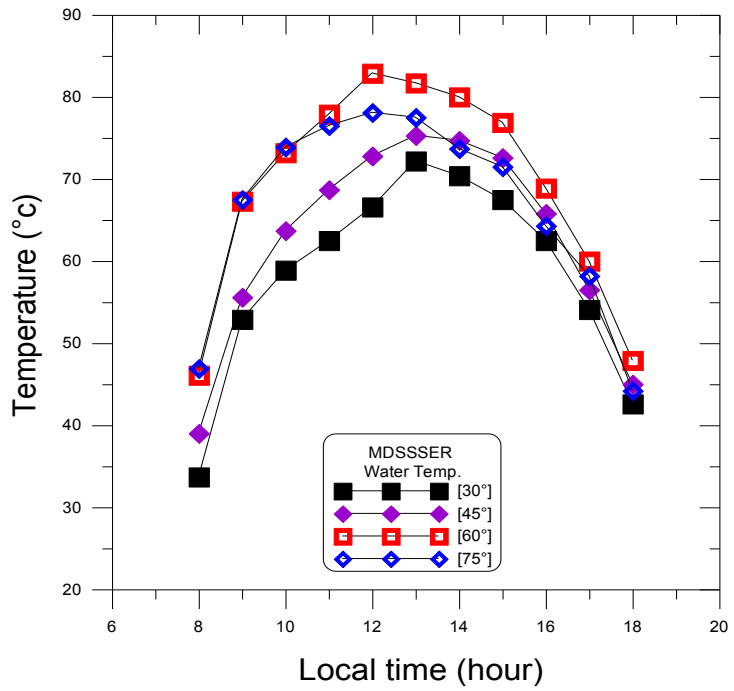

Fig .7a The variation of water temperature with the local time for modified still at various external reflector angles

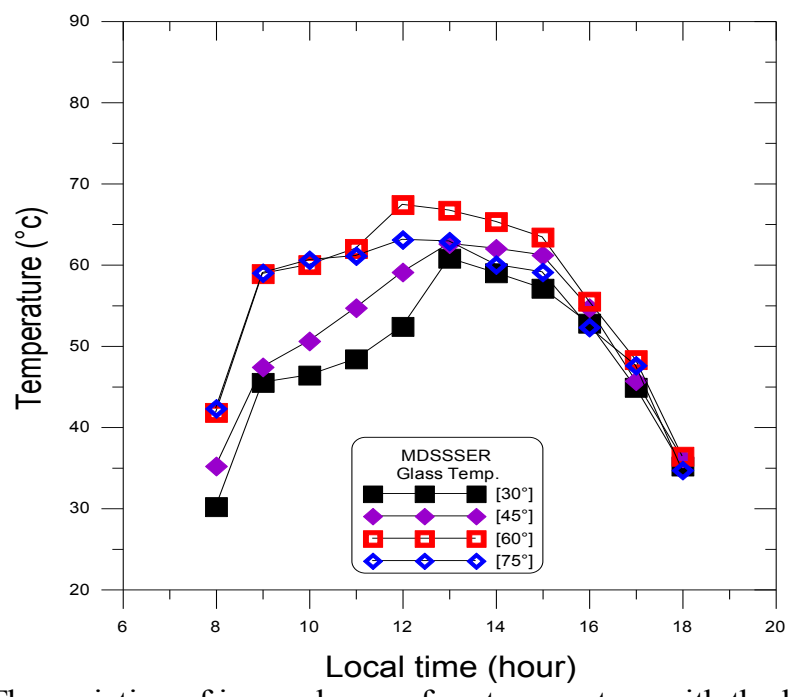

Fig .7b The variation of inner glass surface temperature with the local time for modified still at various external reflector angles

Software has been developed to calculate the values of $\mathrm{C}$ and $\mathrm{n}$ based on experimental data; namely basin water, vapour, glass cover temperatures as well as the distillate output. The computed values of $\mathrm{C}$ and $\mathrm{n}$ for stills are shown in Table 2. It is interesting to note that, $\mathrm{C}=1.001368$ and $\mathrm{n}=0.173616$ for Garshof range of $9.8 \times 10^{6}$ to $5.2 \times 10^{7}$ in the case of $60^{\circ}$ external flat reflector angle.

Tables 3a, 3b, 3c, 3d and Table 4 show the computed values of the convective heat transfer coefficients $\left(\mathrm{h}_{\mathrm{cw}}\right)$, evaporative heat transfer coefficients $\left(\mathrm{h}_{\mathrm{ew}}\right)$, radiative heat transfer coefficients $\left(\mathrm{h}_{\mathrm{rw}}\right)$ and the evaporative transfer rate from water to the glass surface $\left(\dot{\mathrm{q}}_{\mathrm{ew}}\right)$. The Nusselt number $(\mathrm{Nu})$ and the theoretical distillate output for modified double slope solar still with external reflector angles of $30^{\circ}, 45^{\circ}, 60^{\circ}$ and $75^{\circ}$ and conventional double slope solar still are also presented.

Table 2, Computed values of $\mathrm{C}$ and $\mathrm{n}$ for stills

\begin{tabular}{|c|c|c|c|c|}
\hline Still type & $\begin{array}{c}\text { External reflector } \\
\text { angle }\end{array}$ & $\mathrm{C}$ & $\mathrm{n}$ & Gr range \\
\hline MDSSSER & $30^{\circ}$ & 1.000299 & 0.205281 & $8 \times 10^{6}$ To $3.7 \times 10^{7}$ \\
\hline MDSSSER & $45^{\circ}$ & 1.002664 & 0.191707 & $8.4 \times 10^{6}$ To $3.9 \times 10^{7}$ \\
\hline MDSSSER & $60^{\circ}$ & 1.001368 & 0.173616 & $9.8 \times 10^{6}$ To $5.2 \times 10^{7}$ \\
\hline MDSSSER & $75^{\circ}$ & 0.9997 & 0.176949 & $1 \times 10^{7}$ To $4.6 \times 10^{7}$ \\
\hline DSSS & ------- & 1.007428 & 0.203484 & $7 \times 10^{5}$ To $4.3 \times 10^{6}$ \\
\hline
\end{tabular}


The performance of conventional and modified double slope with external reflector angles solar stills are shown in Figure .8 and Figures. 9a, 9b, 9c and 9d respectively. From these figures, it can be observed that, the productivity increases from morning periods to noon and the trend is reversed thereafter. The peak value is obtained between 12 PM and 13 PM for the different reflector angles. For modified double slope solar still with $60^{\circ}$ external reflector angle the maximum value is $1.65 \mathrm{lit} / \mathrm{m}^{2}$ at $12 \mathrm{PM}$ compared with $0.466 \mathrm{lit} / \mathrm{m}^{2}$ for conventional double slope one at the same time with a percentage increase of $254 \%$.

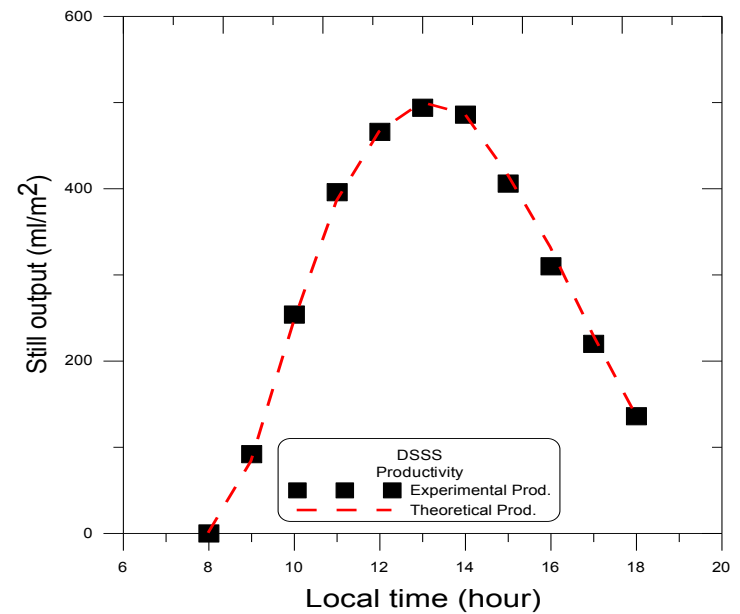

Fig .8 Hourly productivity of conventional double slope solar still (29.06.2013)

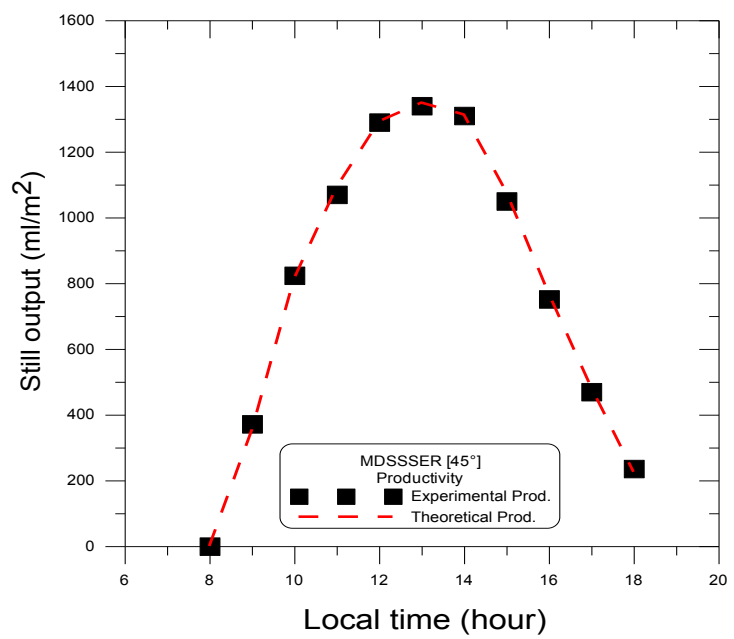

Fig .9b Hourly productivity of modified still with external reflector angle of $45^{\circ}(27.06 .2013)$

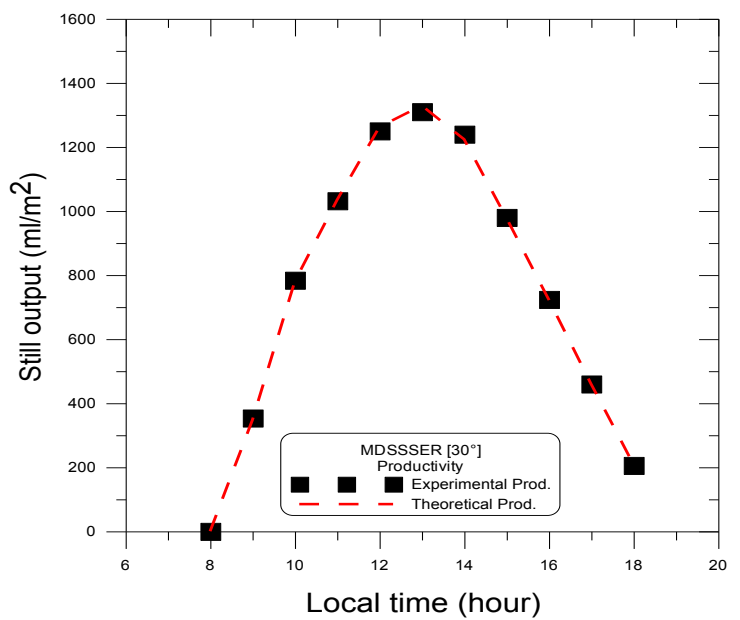

Fig .9a Hourly productivity of modified still with external reflector angle of $30^{\circ}(26.06 .2013)$

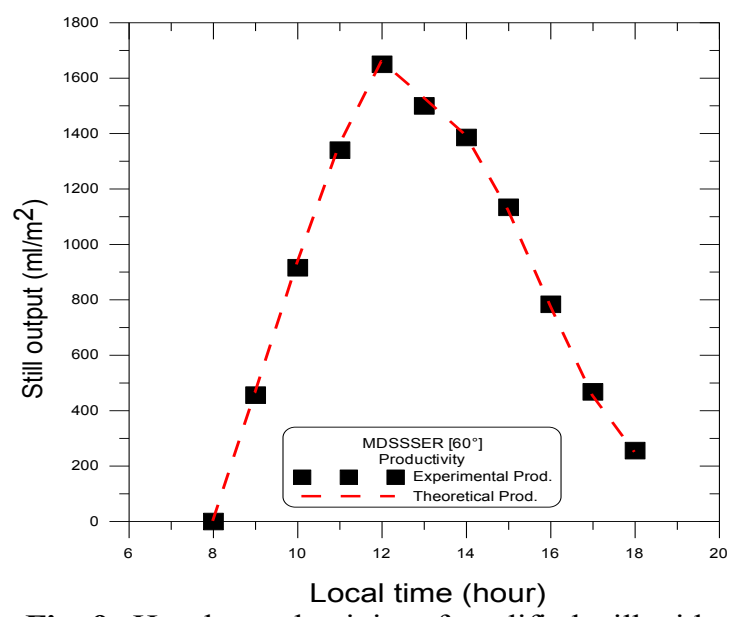

Fig .9c Hourly productivity of modified still with external reflector angle of $60^{\circ}(29.06 .2013)$

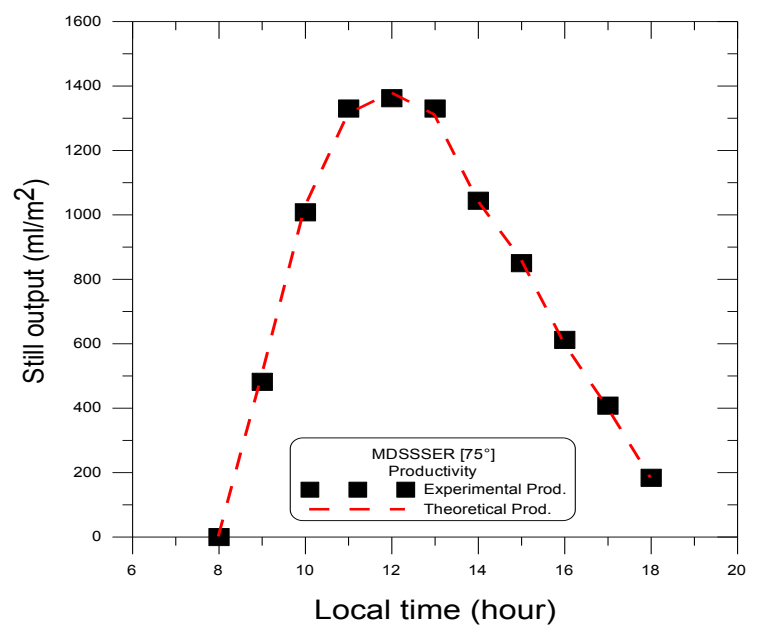

Fig .9d Hourly productivity of modified still with external reflector angle of $75^{\circ}(30.06 .2013)$ 
Table 3a, Computed values of $h_{c w}, h_{e w}, h_{r w}, N u$ and theoretical distillate output for modified values of $\mathrm{C}$ and $\mathrm{n}$ for $30^{\circ}$ external flat reflector angle $\left(C=1.000299\right.$ and $n=0.205281$ for Garshof range of $8 \times 10^{6}$ to $\left.3.7 \times 10^{7}\right)$

\begin{tabular}{|c|c|c|c|c|c|c|c|}
\hline Time & $\begin{array}{l}\text { Exp. distillate } \\
\text { Output } \mathrm{ml} / \mathrm{m}^{2}\end{array}$ & $\begin{array}{l}\text { Theo. distillate } \\
\text { output } \mathrm{ml} / \mathrm{m}^{2}\end{array}$ & $\begin{array}{c}\mathrm{h}_{\mathrm{cw}} \\
\mathrm{W} / \mathrm{m}^{2}{ }^{\circ} \mathrm{C}\end{array}$ & $\begin{array}{c}\mathrm{h}_{\mathrm{ew}} \\
\mathrm{W} / \mathrm{m}^{2}{ }^{\mathrm{o}} \mathrm{C}\end{array}$ & $\begin{array}{c}\mathrm{h}_{\mathrm{rw}} \\
\mathrm{W} / \mathrm{m}^{2}{ }^{\circ} \mathrm{C}\end{array}$ & $\begin{array}{c}\mathrm{q}_{\mathrm{ew}} \\
\mathrm{W} / \mathrm{m}^{2}\end{array}$ & $\mathrm{~N}_{\mathrm{u}}$ \\
\hline 09:00 & 354 & 347 & 3.329 & 31 & 6.44 & 229.4 & 28.44 \\
\hline $10: 00$ & 784 & 780 & 3.768 & 40.93 & 6.65 & 511.7 & 31.70 \\
\hline 11:00 & 1032 & 1034 & 3.917 & 47.96 & 6.82 & 676.2 & 32.74 \\
\hline $12: 00$ & 1250 & 1262 & 4.004 & 57.87 & 7.08 & 821.7 & 33.19 \\
\hline $13: 00$ & 1310 & 1329 & 3.975 & 75.45 & 7.54 & 860.1 & 32.47 \\
\hline $14: 00$ & 1240 & 1223 & 3.932 & 69.59 & 7.42 & 793.3 & 32.16 \\
\hline $15: 00$ & 980 & 978 & 3.804 & 61.18 & 7.26 & 636.2 & 31.26 \\
\hline $16: 00$ & 724 & 723 & 3.659 & 48.75 & 6.96 & 472.8 & 30.50 \\
\hline $17: 00$ & 460 & 460 & 3.487 & 32.96 & 6.46 & 303.2 & 29.67 \\
\hline 18:00 & 206 & 209 & 3.210 & 18.84 & 5.84 & 139.4 & 28.09 \\
\hline
\end{tabular}

Table 3b, Computed values of $\mathrm{h}_{\mathrm{cw}}, \mathrm{h}_{\mathrm{ew}}, \mathrm{h}_{\mathrm{rw}}, \mathrm{Nu}$ and theoretical distillate output for modified values of $\mathrm{C}$ and $\mathrm{n}$ for $45^{\circ}$ external flat reflector angle $\left(C=1.002664, n=0.191707\right.$ for Garshof range of $8.4 \times 10^{6}$ to $\left.3.9 \times 10^{7}\right)$

\begin{tabular}{|c|c|c|c|c|c|c|c|}
\hline Time & $\begin{array}{l}\text { Exp. distillate } \\
\text { Output } \mathrm{ml} / \mathrm{m}^{2}\end{array}$ & $\begin{array}{l}\text { Theo. distillate } \\
\text { output } \mathrm{ml} / \mathrm{m}^{2}\end{array}$ & $\begin{array}{c}\mathrm{h}_{\mathrm{cw}} \\
\mathrm{W} / \mathrm{m}^{2}{ }^{\circ} \mathrm{C}\end{array}$ & $\begin{array}{c}\mathrm{h}_{\mathrm{ew}} \\
\mathrm{W} / \mathrm{m}^{2}{ }^{\mathrm{o}} \mathrm{C}\end{array}$ & $\begin{array}{c}\mathrm{h}_{\mathrm{rw}} \\
\mathrm{W} / \mathrm{m}^{2}{ }^{\circ} \mathrm{C}\end{array}$ & $\begin{array}{c}\mathrm{q}_{\mathrm{ew}} \\
\mathrm{W} / \mathrm{m}^{2}\end{array}$ & $\mathrm{~N}_{\mathrm{u}}$ \\
\hline 09:00 & 372 & 353 & 2.754 & 28.33 & 6.58 & 232.3 & 23.29 \\
\hline $10: 00$ & 824 & 815 & 3.097 & 40.61 & 6.93 & 531.9 & 25.85 \\
\hline 11:00 & 1070 & 1092 & 3.212 & 50.68 & 7.22 & 709.5 & 26.43 \\
\hline $12: 00$ & 1290 & 1292 & 3.274 & 61.01 & 7.50 & 835.9 & 26.64 \\
\hline $13: 00$ & 1340 & 1349 & 3.282 & 68.54 & 7.70 & 870.4 & 26.45 \\
\hline $14: 00$ & 1310 & 1313 & 3.270 & 66.74 & 7.66 & 847.7 & 26.43 \\
\hline $15: 00$ & 1050 & 1078 & 3.173 & 61.16 & 7.56 & 697.2 & 25.73 \\
\hline $16: 00$ & 752 & 769 & 3.044 & 45.13 & 7.13 & 501.0 & 25.12 \\
\hline $17: 00$ & 470 & 483 & 2.901 & 29.43 & 6.56 & 317.9 & 24.60 \\
\hline $18: 00$ & 236 & 226 & 2.683 & 17.06 & 5.94 & 150.1 & 23.37 \\
\hline
\end{tabular}

Table 3c, Computed values of $h_{c w}, h_{e w}, h_{r w}, N u$ and theoretical distillate output for modified values of $\mathrm{C}$ and $\mathrm{n}$ for $60^{\circ}$ external flat reflector angle $\left(\mathrm{C}=1.001368, \mathrm{n}=0.173616\right.$ for Garshof range of $9.8 \times 10^{6}$ to $\left.5.2 \times 10^{7}\right)$

\begin{tabular}{|c|c|c|c|c|c|c|c|}
\hline Time & $\begin{array}{l}\text { Exp. distillate } \\
\text { Output } \mathrm{ml} / \mathrm{m}^{2}\end{array}$ & $\begin{array}{l}\text { Theo. distillate } \\
\text { output } \mathrm{ml} / \mathrm{m}^{2}\end{array}$ & $\begin{array}{c}\mathrm{h}_{\mathrm{cw}} \\
\mathrm{W} / \mathrm{m}^{2}{ }^{\mathrm{o}} \mathrm{C}\end{array}$ & $\begin{array}{c}\mathrm{h}_{\mathrm{ww}} \\
\mathrm{W} / \mathrm{m}^{2}{ }^{\mathrm{o}} \mathrm{C}\end{array}$ & $\begin{array}{c}\mathrm{h}_{\mathrm{rw}} \\
\mathrm{W} / \mathrm{m}^{2}{ }^{\mathrm{o}} \mathrm{C}\end{array}$ & $\begin{array}{c}\mathrm{q}_{\mathrm{ew}} \\
\mathrm{W} / \mathrm{m}^{2}\end{array}$ & $\mathrm{~N}_{\mathrm{u}}$ \\
\hline 09:00 & 456 & 463 & 2.165 & 35.86 & 7.31 & 301.2 & 17.74 \\
\hline $10: 00$ & 916 & 932 & 2.391 & 45.65 & 7.54 & 602.6 & 19.51 \\
\hline $11: 00$ & 1340 & 1358 & 2.523 & 54.96 & 7.77 & 873.9 & 20.33 \\
\hline $12: 00$ & 1650 & 1659 & 2.594 & 68.52 & 8.13 & 1061.9 & 20.52 \\
\hline $13: 00$ & 1500 & 1528 & 2.562 & 65.30 & 8.06 & 979.5 & 20.38 \\
\hline $14: 00$ & 1386 & 1392 & 2.527 & 60.80 & 7.95 & 893.7 & 20.24 \\
\hline $15: 00$ & 1134 & 1123 & 2.449 & 53.58 & 7.78 & 723.3 & 19.84 \\
\hline $16: 00$ & 784 & 778 & 2.344 & 37.69 & 7.25 & 505.1 & 19.16 \\
\hline $17: 00$ & 468 & 454 & 2.201 & 25.44 & 6.74 & 297.6 & 18.48 \\
\hline $18: 00$ & 256 & 249 & 2.098 & 14.37 & 6.03 & 165.3 & 18.08 \\
\hline
\end{tabular}

Table 3d, Computed values of $h_{\mathrm{cw}}, \mathrm{h}_{\mathrm{ew}}, \mathrm{h}_{\mathrm{rw}}, \mathrm{Nu}$ and theoretical distillate output for modified values of $\mathrm{C}$ and $\mathrm{n}$ for $75^{\circ}$ external flat reflector angle $\left(C=0.9997\right.$ and $n=0.176949$ for Garshof range of $1 \times 10^{7}$ to $\left.4.6 \times 10^{7}\right)$

\begin{tabular}{|c|c|c|c|c|c|c|c|}
\hline Time & $\begin{array}{l}\text { Exp. distillate } \\
\text { Output } \mathrm{ml} / \mathrm{m}^{2}\end{array}$ & $\begin{array}{l}\text { Theo. distillate } \\
\text { output } \mathrm{ml} / \mathrm{m}^{2}\end{array}$ & $\begin{array}{c}\mathrm{h}_{\mathrm{cw}} \\
\mathrm{W} / \mathrm{m}^{2}{ }^{\circ} \mathrm{C}\end{array}$ & $\begin{array}{c}\mathrm{h}_{\mathrm{ew}} \\
\mathrm{W} / \mathrm{m}^{2}{ }^{\circ} \mathrm{C} \\
\end{array}$ & $\begin{array}{c}\mathrm{h}_{\mathrm{rw}} \\
\mathrm{W} / \mathrm{m}^{2}{ }^{\circ} \mathrm{C} \\
\end{array}$ & $\begin{array}{c}\mathrm{q}_{\mathrm{ew}} \\
\mathrm{W} / \mathrm{m}^{2}\end{array}$ & $\mathrm{~N}_{\mathrm{u}}$ \\
\hline 09:00 & 482 & 499 & 2.290 & 38.17 & 7.32 & 324.4 & 18.76 \\
\hline $10: 00$ & 1008 & 1024 & 2.539 & 49.73 & 7.59 & 661.4 & 20.71 \\
\hline 11:00 & 1330 & 1312 & 2.635 & 54.92 & 7.69 & 845.7 & 21.25 \\
\hline $12: 00$ & 1362 & 1378 & 2.650 & 59.09 & 7.81 & 886.4 & 21.24 \\
\hline $13: 00$ & 1330 & 1310 & 2.631 & 57.74 & 7.79 & 843.0 & 21.10 \\
\hline $14: 00$ & 1044 & 1043 & 2.549 & 49.18 & 7.56 & 673.8 & 20.67 \\
\hline $15: 00$ & 850 & 861 & 2.481 & 44.99 & 7.46 & 557.9 & 20.24 \\
\hline $16: 00$ & 612 & 600 & 2.380 & 32.65 & 7.00 & 391.8 & 19.74 \\
\hline $17: 00$ & 408 & 401 & 2.271 & 24.86 & 6.67 & 263.5 & 19.11 \\
\hline 18:00 & 184 & 183 & 2.120 & 12.80 & 5.87 & 121.6 & 18.54 \\
\hline
\end{tabular}


Table 4, Computed values of $\mathrm{h}_{\mathrm{cw}}, \mathrm{h}_{\mathrm{ew}}, \mathrm{h}_{\mathrm{rw}}, \mathrm{Nu}$ and theoretical distillate output for modified values of $\mathrm{C}$ and $\mathrm{n}$ for conventional double slope solar still $\left(C=1.007428\right.$ and $n=0.203484$ for Garshof range of $7 \times 10^{5}$ to $\left.4.3 \times 10^{6}\right)$

\begin{tabular}{|c|c|c|c|c|c|c|c|}
\hline Time & $\begin{array}{l}\text { Exp. distillate } \\
\text { Output } \mathrm{ml} / \mathrm{m}^{2}\end{array}$ & $\begin{array}{l}\text { Theo. distillate } \\
\text { output } \mathrm{ml} / \mathrm{m}^{2}\end{array}$ & $\begin{array}{c}\mathrm{h}_{\mathrm{cw}} \\
\mathrm{W} / \mathrm{m}^{2}{ }^{\mathrm{o}} \mathrm{C}\end{array}$ & $\begin{array}{c}\mathrm{h}_{\mathrm{ew}} \\
\mathrm{W} / \mathrm{m}^{2} \mathrm{o} \mathrm{C}\end{array}$ & $\begin{array}{c}\mathrm{h}_{\mathrm{rw}} \\
\mathrm{W} / \mathrm{m}^{2}{ }^{\mathrm{o}} \mathrm{C}\end{array}$ & $\begin{array}{c}\mathrm{q}_{\mathrm{ew}} \\
\mathrm{W} / \mathrm{m}^{2}\end{array}$ & $\mathrm{~N}_{\mathrm{u}}$ \\
\hline 09:00 & 92 & 83 & 2.844 & 28.95 & 6.57 & 55.0 & 17.05 \\
\hline $10: 00$ & 254 & 245 & 3.317 & 48.67 & 7.12 & 160.6 & 19.44 \\
\hline $11: 00$ & 396 & 385 & 3.510 & 73.43 & 7.72 & 249.7 & 20.11 \\
\hline $12: 00$ & 466 & 466 & 3.614 & 81.42 & 7.85 & 301.2 & 20.61 \\
\hline $13: 00$ & 492 & 500 & 3.653 & 84.97 & 7.91 & 322.9 & 20.76 \\
\hline $14: 00$ & 486 & 486 & 3.655 & 75.04 & 7.67 & 315.2 & 20.95 \\
\hline $15: 00$ & 406 & 416 & 3.587 & 62.98 & 7.41 & 270.8 & 20.78 \\
\hline $16: 00$ & 310 & 332 & 3.524 & 45.33 & 6.91 & 217.6 & 20.82 \\
\hline $17: 00$ & 220 & 230 & 3.407 & 31.66 & 6.44 & 152.0 & 20.57 \\
\hline $18: 00$ & 136 & 137 & 3.258 & 20.30 & 5.92 & 91.3 & 20.17 \\
\hline
\end{tabular}

Comparisons between hourly and accumulative productivities for the two tested stills are shown in Figures. 10a and $10 \mathrm{~b}$ respectively. It is seen that the amount of accumulated distillate water with $60^{\circ}$ external reflector is higher than that of the other angles of $30^{\circ}, 45^{\circ}$ and $75^{\circ}$ for modified double slope solar and also for conventional double slope solar still.

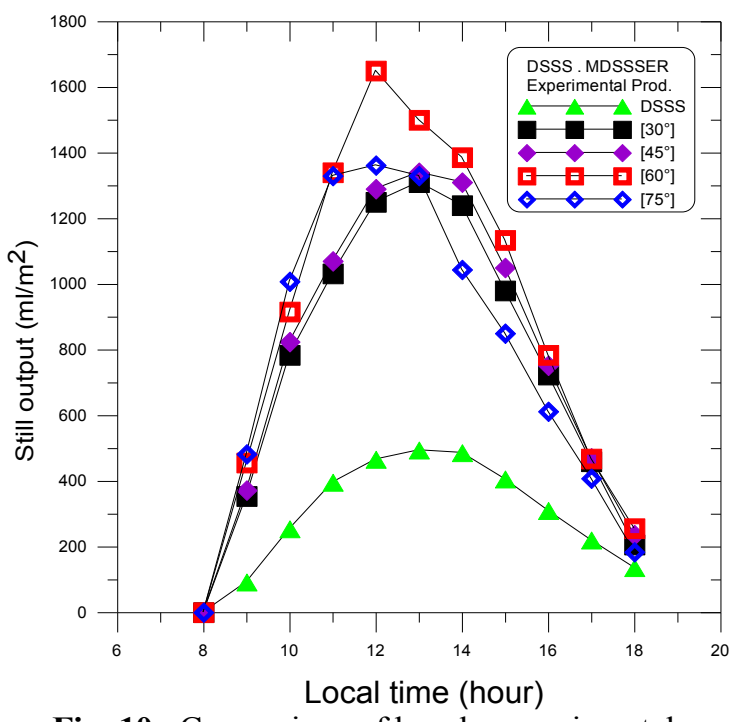

Fig .10a Comparison of hourly experimental productivities for two stills

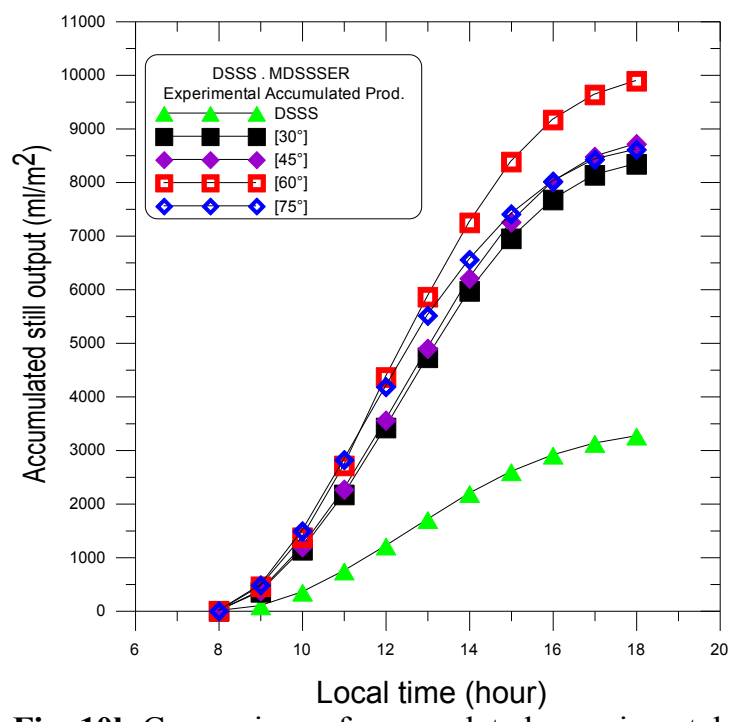

Fig .10b Comparison of accumulated experimental productivities for two stills

Figures. 11 and 12 illustrate the hourly variation of the heat transfer coefficients within the still enclosure at different reflector angles. It is clear that the evaporative mass transfer rate is strongly influenced by the evaporative heat transfer coefficient and it increases when the evaporative heat transfer coefficient is increased. This can be observed when corresponding values of $\mathrm{V}_{\mathrm{w}}$ and $\mathrm{h}_{\mathrm{ew}}$ shown in figures. 10a and 12 are compared. It is also seen that the evaporative heat transfer coefficient has a maximum values at the noon period and reaches to about $86.8 \%$ of the total heat transfer coefficients, while the convective mode has a minimum value and represents about $4.6 \%$ at the same period.

The radiative heat transfer mainly depends on water and glass temperatures. The radiative heat transfer mode dominates at external reflector angle of $60^{\circ}$ for all the sunshine hours. This is the reason why Figure .13 shows the values of $\mathrm{h}_{\mathrm{rw}}$ high in comparison with other external reflector angles.

It is very interesting to note that, the value of hew is high for the external reflector angle of $30^{\circ}$ (Figure. 12); but the hourly productivity is low for the same period as can be seen in Figure. 10a, especially at sunshine hours. This is because of the fact that, productivity is the product of evaporative heat transfer and the temperature difference and if either of these two quantities is low the productivity will be low.

Convective heat and mass transfer coefficients are important parameters, which are a measure of the resistance to heat and mass transfer between the water surface and the fluid flowing over that surface. Figure. 14 shows the Nusselt number ( $\mathrm{Nu}$ ) as a function of the Grashof and Prandtl numbers (Gr.Pr); i.e., Rayleigh number $(\mathrm{Ra})$, for the various external reflector angles tested. The $\mathrm{Nu}$ values increases with increasing the Ra number for all angles. The Nu decreases with increasing the external reflector tilt angle from $30^{\circ}$ to $60^{\circ}$, after tilt angle $60^{\circ}$, the $\mathrm{Nu}$ increases with increasing the external reflector tilt angle. 


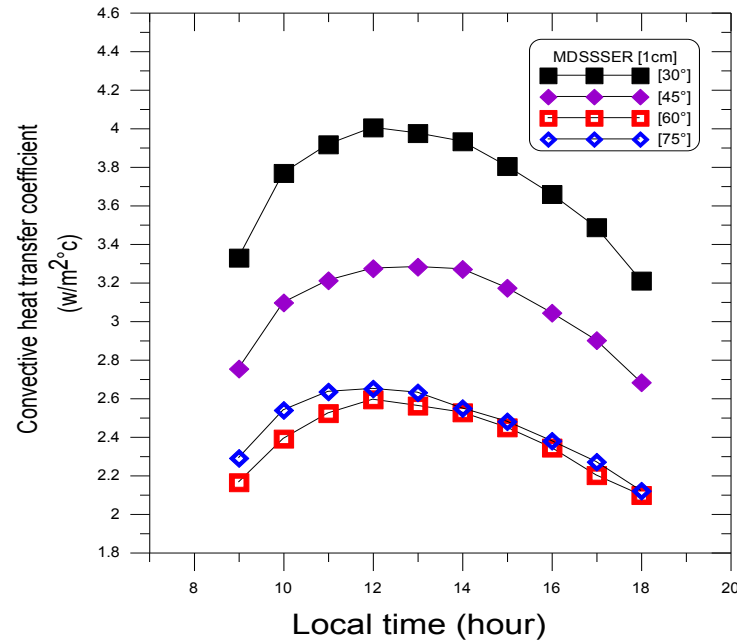

Fig .11 Variation of convective heat transfer coefficient $\left(\mathrm{h}_{\mathrm{cw}}\right)$ for various external reflector angles

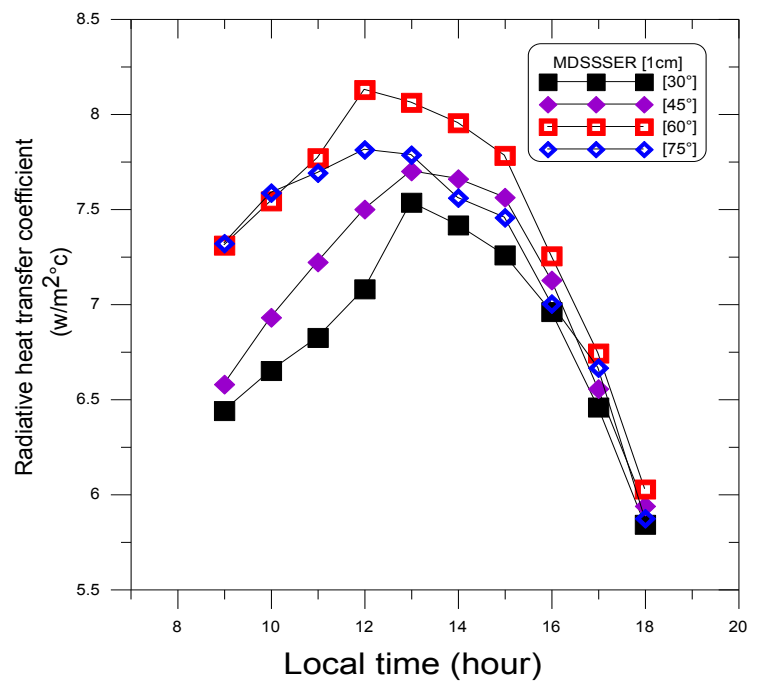

Fig .13 Variation of radiative heat transfer coefficient $\left(\mathrm{h}_{\mathrm{rw}}\right)$ for various external reflector angles

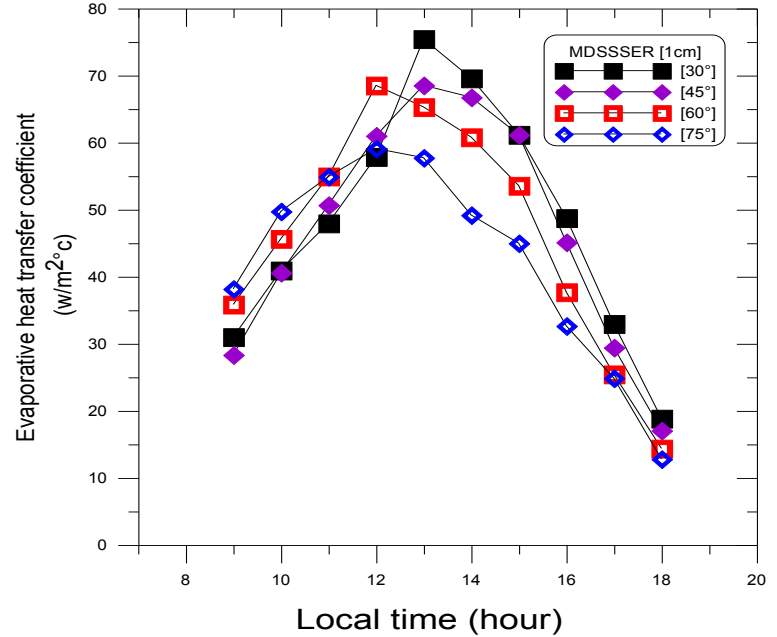

Fig .12 Variation of evaporative heat transfer coefficient $\left(\mathrm{h}_{\mathrm{ew}}\right)$ for various external reflector angles

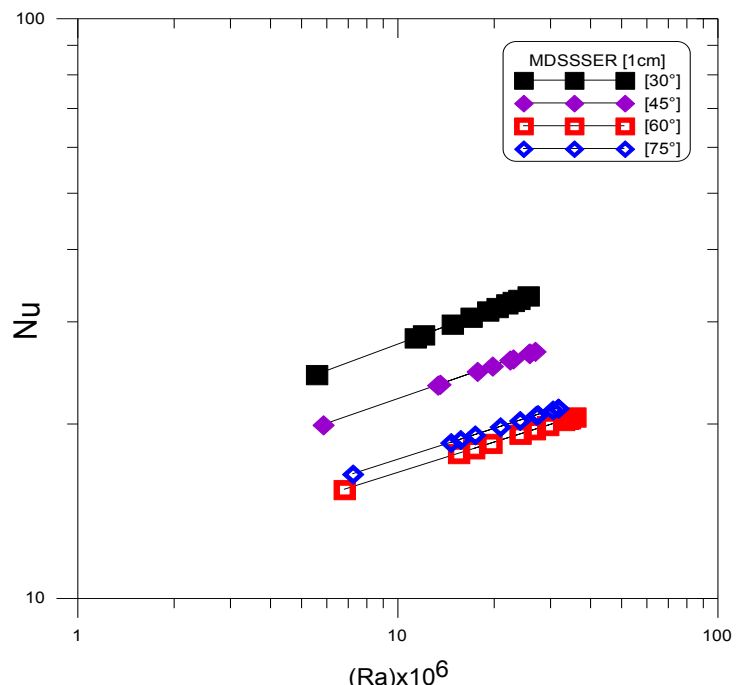

Fig .14 Variation of Nusselt number with Rayleigh number for various external reflector angles

\section{CONCLUSIONS}

The best external reflector angle of modified double slope solar for $1 \mathrm{~cm}$ water depth in Egyptian climatic conditions is $60^{\circ}$ with a maximum daily productivity of $9.89 \mathrm{lit} / \mathrm{m}^{2}$.

The productivity increases by $4.48 \%$ when the external reflector angle changes from $30^{\circ}$ to $45^{\circ}$ while it increases by $13.5 \%$ when angle changes from $45^{\circ}$ to $60^{\circ}$.

The productivity decreases by $12.94 \%$ when the external reflector angle changes from $60^{\circ}$ to $75^{\circ}$.

The performance of solar stills cannot be evaluated precisely unless the values of $\mathrm{C}$ and $\mathrm{n}$ are validated experimentally. Therefore, it is recommended that before predicting the performance parameters theoretically, an experiment may be carried out on a particular model of still for a given climatic condition to evaluate the values of $\mathrm{C}$ and $\mathrm{n}$.

The proposed empirical correlation obtained is $\mathrm{Nu}=1.001368[\mathrm{Ra}]^{0.173616}$ for Garshof number ranging from $9.8 \times 106$ to $5.2 \times 107$ for modified double slope solar still with external reflector angle of $60^{\circ}$. 


\section{NOMENCLATURE}

$\mathrm{A}_{\mathrm{s}} \quad$ Basin liner still area

$\mathrm{A}_{\mathrm{ss}} \quad$ Side still area

$\mathrm{h}_{\mathrm{cg}} \quad$ Glass cover convection heat transfer coefficient

$\mathrm{W} / \mathrm{m}^{2}{ }^{\circ} \mathrm{C}$

$\mathrm{h}_{\mathrm{rg}} \quad$ Glass cover radiative heat transfer coefficient

$\mathrm{h}_{\mathrm{tg}} \quad$ Total glass heat transfer loss coefficient

$\mathrm{h}_{\mathrm{cp}} \quad$ Basin liner convection heat transfer coefficient

$\mathrm{W} / \mathrm{m}^{2}{ }^{\circ} \mathrm{C}$

$\mathrm{h}_{\mathrm{rp}} \quad$ Basin liner radiative heat transfer coefficient

$h_{w} \quad$ Convective heat transfer coefficient from basin to water

$h_{b} \quad$ Basin liner overall heat transfer coefficient

$\mathrm{h}_{\mathrm{cw}}$ Heat loss coefficient by convection from water surface

$h_{e w}$ Heat loss coefficient by evaporation from water surface

$\mathrm{h}_{\mathrm{rw}}$ Basin water radiative heat transfer coefficient

$\mathrm{h}_{\mathrm{tw}}$ Total water surface heat transfer loss coefficient

$\mathrm{k}_{\text {ins }}$ Insulation thermal conductivity

$\mathrm{L}_{\text {ins }}$ Insulation thickness

$\dot{\mathrm{q}}_{\mathrm{g}} \quad$ Rate of total energy from the glass cover

$\mathrm{W} / \mathrm{m}^{2}{ }^{\circ} \mathrm{C}$

$\mathrm{W} / \mathrm{m}^{2}{ }^{\circ} \mathrm{C}$

$\dot{\mathrm{q}}_{\mathrm{cg}}$ Rate of energy lost from the glass cover by convective

$\mathrm{W} / \mathrm{m}^{2}{ }^{\circ} \mathrm{C}$

$\mathrm{W} / \mathrm{m}^{2}{ }^{\circ} \mathrm{C}$

$\dot{\mathrm{q}}_{\mathrm{rg}}$ Rate of energy lost from the glass cover by radiation

$\mathrm{W} / \mathrm{m}^{2}{ }^{\circ} \mathrm{C}$

$\mathrm{W} / \mathrm{m}^{2}{ }^{\circ} \mathrm{C}$

$\mathrm{W} / \mathrm{m}^{2}{ }^{\circ} \mathrm{C}$

$\mathrm{W} / \mathrm{m}^{2}{ }^{\circ} \mathrm{C}$

$\mathrm{W} / \mathrm{m}^{2}{ }^{\circ} \mathrm{C}$

$\mathrm{W} / \mathrm{m}^{\circ} \mathrm{C}$

$\mathrm{m}$

$\mathrm{W} / \mathrm{m}^{2}$

$\mathrm{W} / \mathrm{m}^{2}$

$\mathrm{W} / \mathrm{m}^{2}$

$\dot{\mathrm{q}}_{\mathrm{rw}}$ Rate of energy lost from water surface by radiation

$\mathrm{W} / \mathrm{m}^{2}$

$\dot{\mathrm{q}}_{\mathrm{cw}}$ Rate of energy lost from water surface by convection

$\mathrm{W} / \mathrm{m}^{2}$

$\dot{\mathrm{q}}_{\mathrm{ew}}$ Rate of energy lost from water surface by evaporation

$\mathrm{W} / \mathrm{m}^{2}$

$\dot{\mathrm{q}}_{\mathrm{tw}}$ Rate of total energy transfer within still from water to glass

$\mathrm{W} / \mathrm{m}^{2}$

$\mathrm{T}_{\mathrm{w}} \quad$ Still water temperature

$\mathrm{T}_{\mathrm{g}} \quad$ Still glass cover

$\mathrm{T}_{\mathrm{v}} \quad$ Still vapour temperature

$\mathrm{T}_{\mathrm{a}}$ Ambient temperature

$\mathrm{T}_{\text {sky }}$ Sky temperature

$\mathrm{P}_{\mathrm{w}}$ Water saturated partial pressure

$\mathrm{P}_{\mathrm{g}} \quad$ Glass saturated partial pressure

$\mathrm{v} \quad$ Wind speed

$\mathrm{x}$ Average spacing between water surface and glass cover

$\mathrm{k}$ Thermal conductivity of humid air

$\mathrm{C}_{\mathrm{p}}$ Specific heat capacity of humid air

$\mathrm{g}$ Acceleration due to gravity

$\dot{\mathrm{M}}_{\mathrm{w}}$ Hourly distillate output

L Latent heat of humid air

$\mathrm{U}_{\mathrm{b}}$ Overall bottom heat lost coefficient

$\mathrm{U}_{\mathrm{e}}$ Overall side heat loss coefficient

$\mathrm{Nu}$ Nusselt number

Gr Grashoff number

Pr Prandtl number

Ra Rayleigh number

C Unknown constant in Nusselt number expression

$\mathrm{n}$ Unknown constant in Nusselt number expression

$\mathrm{R}$ Constant

$\mathrm{N}$ number of experimental observations 


\section{GREEK SYMBOLS}

$\varepsilon_{\text {eff }}$ Effective emissivity

$\varepsilon_{\mathrm{w}}$ Emissivity of water

$\varepsilon_{\mathrm{g}} \quad$ Nusselt number

$\beta \quad$ Expansion factor

$\sigma \quad$ Stephan-Boltzman coefficient

$\rho$ Density of humid air

$\mu \quad$ Dynamic viscosity of humid air

$\mathrm{W} / \mathrm{m}^{2} \cdot \mathrm{K}^{4}$

$\mathrm{kg} / \mathrm{m}^{3}$

ABBREVIATIONS

MDSSSER

DSSS

Modified Double Slope Solar Still with External Reflector

Double Slope Solar Still

\section{REFERENCES}

[1] Soteris A. Kalogirou., Seawater desalination using renewable energy sources. Progress in Energy and Combustion Science, 2005, $31 ; 242-281$

[2] Tiwari GN, Tiwari A., Solar distillation practice for water desalination systems. New Delhi (India): Anamaya, 2007.

[3] Kuwait Pike JG., Ground water resources development and the environment in the central region of the Arabian Gulf. Int J Water Resources Develop; 1983, 1:115-32.

[4] A.E. Kabel, S.A. El-Agouz, Review of researches and developments on solar stills, Desalination, 2011, $276,1-12$.

[5] A.K. Tiwari, G.N. Tiwari., Effect of water depths on heat and mass transfer in a passive solar still: In summer climatic condition, Desalination, 2006, 195, 78-94.

[6] E. Chafik., A new Type of Seawater Desalination Plants Using Solar Energy, Desalination, 2003, 156, 333-348.

[7] M. Boubekri, A. Chaker, Yield of an improved solar still : numerical approach, Energy Proscedia, 2011, 6, 610-617.

[8] Malik, M.A.S., Tiwari, G.N., Kumar, A. and Sodha, M.S., Solar Distillation, UK: Pergamon Press, 1982.

[9] Sampathkumar, K., Arjunan, T.V., Pitchandi, P. and Senthilkumar P., Active solar distillation - A detailed review, Renewable and Sustainable Energy Reviews, 2010, Vol. 14, pp.1503-1526.

[10] G.N.Tiwari, "Solar Energy". Narosa Publishing House. New Delhi, 2002.

[11] Dunkle, R. V., Solar water distillation: The roof type still and a multiple effect diffusion still. Int. Development in Heat Transfer, ASME, Proc. Int. Hear Transfer, Part V, University of Colorado, 1961, p. 895.

[12] G.N.Tiwari, A.Minocha, P.B. Sharma, M. Emran Khan, Simulation of convective mass transfer in a solar distillation process. Energy Convers. Mgmr, 1997, Vol. 38, No. 8, pp. 761-770. 